\title{
AIDS-Related Cervical Kaposi Sarcoma
}

National Cancer Institute

\section{Source}

National Cancer Institute. AIDS-Related Cervical Kaposi Sarcoma. NCI Thesaurus. Code C7433.

A Kaposi sarcoma arising from the cervix in patients who are infected with the human immunodeficiency virus. 